\title{
THE EFFECT OF GOVERNMENT ACCOUNTING STANDARDS BASED ON AKRUAL, USING INFORMATION TECHNOLOGY, INTERNAL GOVERNMENT CONTROL SYSTEM AND ORGANIZATION COMMITMENT TO QUALITY OF CENTRAL GOVERNMENT FINANCIAL REPORT
}

\author{
Januarti Tiurmaida \\ Trisakti University \\ 317tiurmaida@gmail.com
}

\begin{abstract}
The purpose of this study is to determine the effect of the implementation of Accounting Standards Based on Accrual Government, Utilization of Information Technology, Government Internal Control System, and Organizational Commitment to the quality of Central Government Financial Report. Central Government Financial Report is an accountability report on budget execution by Ministry / Institution. The population of research is conducted on the Ministry / Institution, with data acquisition by distributing questionnaires to the compilers of financial statements. The use of method in this research is quantitative with causal relation which is research to know influence between one independent variable (Accrual Based Government Accounting Standards, Information Technology, Government Internal Control System and Organizational Commitment) to dependent variable (Quality of Central Government Financial Report). The results of the study prove that all independent variables positively affect the quality of the Central Government Financial Statements.
\end{abstract}

Keywords: Quality of Central Government Financial Statements, Government Accounting Standards, Accrual Based, Information Technology, Government Internal Control System, and Organizational Commitment.

\begin{abstract}
Abstrak
Tujuan penelitian ini adalah untuk mengetahui pengaruh penerapan Standar Akuntansi Berbasis Akrual Pemerintah, Pemanfaatan Teknologi Informasi, Sistem Pengendalian Internal Pemerintah, dan Komitmen Organisasi terhadap kualitas Laporan Keuangan Pemerintah Pusat. Laporan Keuangan Pemerintah Pusat adalah laporan pertanggungjawaban atas pelaksanaan anggaran oleh Kementerian / Lembaga. Populasi penelitian dilakukan pada Kementerian / Lembaga, dengan akuisisi data dengan menyebarkan kuesioner kepada para penyusun laporan keuangan. Penggunaan metode dalam penelitian ini adalah kuantitatif dengan hubungan kausal yaitu penelitian untuk mengetahui pengaruh antara satu variabel
\end{abstract}


independen (Standar Akuntansi Keuangan Berbasis Akrual, Teknologi Informasi, Sistem Pengendalian Intern Pemerintah dan Komitmen Organisasi) terhadap variabel dependen (Kualitas Laporan Keuangan Pemerintah Pusat ). Hasil penelitian membuktikan bahwa semua variabel independen berpengaruh positif terhadap kualitas Laporan Keuangan Pemerintah Pusat.

Kata Kunci: Kualitas Laporan Keuangan Pemerintah Pusat, Standar Akuntansi Pemerintahan, Berbasis Akrual, Teknologi Informasi, Sistem Pengendalian Internal Pemerintah, dan Komitmen Organisasi.

\section{INTRODUCTION}

The government's financial report is a media of responsibility for the implementation of state financial management by the President to the legislative body. The Financial Statement prior to submission to the People's Legislative Assembly shall be examined by the Supreme Audit Board in order to provide an opinion statement on the quality of the fairness of the information presented. Since the commencement of the preparation of the financial statements by the government in 2004, the quality of the government financial statements, from year to year since the improvement, is indicated by the improvement of opinion of the Supreme Audit Board on the audit of the Central Government Financial Report. The opinion of the Supreme Audit Agency which was first obtained on the 2004 Financial Statement was "disclaimer" or did not give an opinion, but by 2016, the opinion obtained by the government is "Unqualified". Examination of the Supreme Audit Board of government financial reporting includes compliance with generally accepted Accounting Principles of Accounting and internal control of the preparation of financial statements.

At the beginning of the preparation of the 2004 government financial statements, the accounting standards used were cash-based, but went on to become the basis of Cash Toward Accrual. And by 2015 as stipulated in Government Regulation 71 of 2010, government financial reporting uses the accrual basis of accounting standards in full. Cash Toward Accrual accounting base is a recording base that combines cash basis and accrual basis, ie reporting on budget execution using cash basis, while in Balance using accrual basis. The accrual basis of accounting is the recognition and recording of transactions at the time of the transaction. The accrual basis can capture information that was not previously captured in the Cash Toward Accrual basis. Among other non-tax State Revenue information still to be received are presented in the Operational Report and Balance Sheet, whereas previously in the cash basis only recorded on the Balance Sheet.

The preparation of financial statements can not be separated from the control mechanism for financial reporting activities as regulated in Government Regulation Number 60 of 2008 regarding Government Internal Control System, which stipulates that in order to achieve financial reporting reliability, the 
government maintains an internal control system to provide reasonable assurance to the financial statements compiled by the government. One of the elements of the Internal Control System is the control environment, in the environment and control, the Leadership of Government Institutions and all employees must create and maintain the environment within the whole organization that raises positive and supportive behavior towards internal control and sound management.

Based on the above description of the background, the authors assume that research needs to be done to see if there is influence of the implementation of Accrual Government Accounting Standards, the utilization of information technology, Government Internal Control System and organizational commitment to the quality performance of the Central Government Financial Report. Based on the above exposure, the research question is: "Is there influence of the implementation of Accrual Based Government Accounting, of information technology utilization, Government Internal Control System, and the organization's commitment to the quality of the Central Government Financial Statements"?

\section{LITERATURE REVIEW}

\subsection{Quality of Central Government Financial Statements}

To be able to meet the presentation of state financial position information to the stakeholders, quality reports should be produced. Definition of quality according to Mulyana (2010: 96), namely: "Quality is defined as compliance with standards, measured based on levels of non-conformity, and achieved through examination". In Government Regulation 71 of 2010, defining qualitative characteristics of financial statements are normative measures that need to be met to meet quality financial statements, including relevant, reliable, comparable, and understandable.

\subsection{Accrual Based Government Accounting Standards}

Definition of Government Accounting Standards according to Government Regulation 71 of 2010 are accounting principles applied in preparing and presenting government financial statements. The accounting principles adopted in the preparation of the Government's financial statements are based on the accrual basis, which is the recording of financial transactions based on the recognition of the rights and obligations, not on the basis of cash flows which include Balance Sheet, Operational Report and Statement of Changes in Equity. Dr. Akbar Amini Mehr, Singaporean Journal of Businness Economic \& Management Studies (2015), Accrual accounting standards have a significant influence on the validity of the presentation of public sector financial reporting.

\subsection{Government Internal Control System}

In Government Regulation 60 of 2008 on Government Internal Control System, the definition of internal control is the whole process of audit activities, review, evaluation, monitoring and other oversight activities on the organization 
of duties and functions of the organization in order to provide reasonable assurance that the activities have been carried out in accordance with benchmarks that have been established effectively and efficiently for the interests of the leadership in realizing good governance. Internal supervision is carried out by the Government Internal Supervisory Apparatus. The purpose of internal controls is to provide reasonable assurance on the achievement of organizational goals through effective and efficient activities, reliability of financial reporting, security of state assets, and compliance with laws and regulations.

\subsection{Information Technology}

Utilization is at the level where a person believes that the use of a particular technology will improve the person's achievement, where the measurement of usefulness is based on the frequency and diversity of the technology used. Information technology is a technology used to store, process, produce and disseminate information. Information technology is to utilize computer technology. Information technology is needed by humans to cope with human slowness if working manually.

\subsection{Organizational Commitment}

Richard M. Steers (Sri Kuntjoro, 2002) defines organizational commitment as a sense of trust in organizational values, a willingness to do the best possible for the benefit of the organization and a desire to remain a member of the organization concerned by an employee of the organization. Steers argues that organizational commitment is a condition in which employees are very interested in the goals, values, and objectives of the organization. Commitment to the organization means more than just formal membership, as it includes an attitude of liking to the organization and a willingness to seek high levels of effort for the benefit of the organization for the achievement of the goal. Silviana, (2012) The commitment of regional heads has a significant influence on the quality of government financial reports.

Based on the above, the conceptual framework of research is built to examine the relationship between four independent variables, namely Accrual Government Accounting Standards, information technology, Government Internal Control System and commitment and one dependent variable, Central Government Finance. The relationships of these variables are described as follows: 


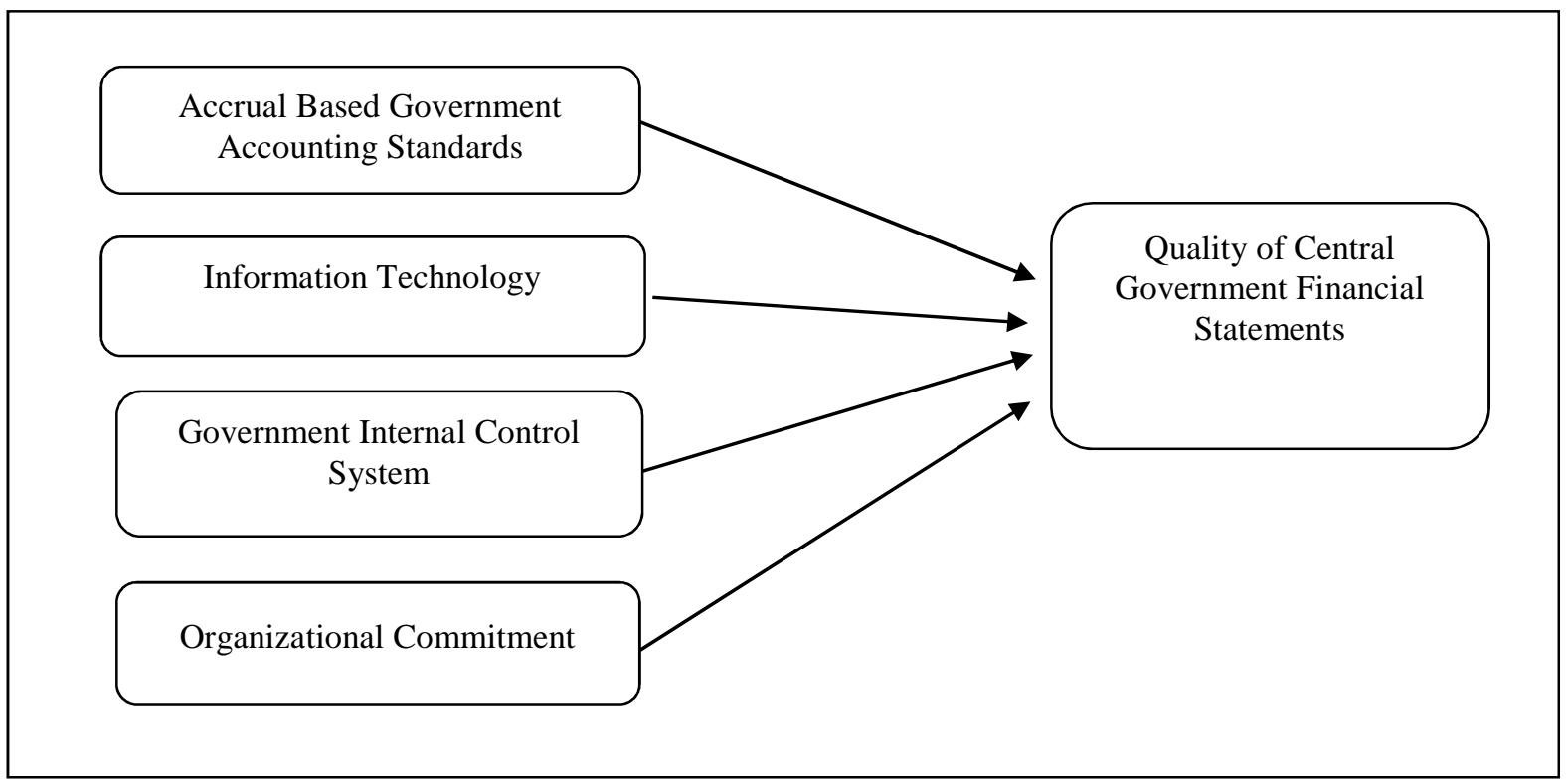

\subsection{Development of Hypotheses}

According to Sekaran (2007), the hypothesis can be defined as a logically expected relationship between two variables in the form of a logical question. Based on the description of the background and conceptual framework, the hypothesis, namely:

1. The implementation of Accrual Based Government Accounting Standards have a positive effect on Central Government Financial Report, with hypothesis:

H0 : The implementation of Accrual Based Government Accounting Standards has no effect on the quality of the Central Government Financial Statements.

H1 : The implementation of Accrual Based Government Accounting Standards influences the quality of Central Government Financial Statements

2. Utilization of information technology positively affect the quality of Central Government Financial Statements, with the hypothesis:

H0 : Utilization of information technology does not affect the quality of Central Government Financial Report.

H1 : Utilization of information technology affect the quality of Central Government Financial Report.

3. The Government's Internal Control System has a positive effect on the Quality of Central Government Financial Statements, with the hypothesis:

H0 : Implementation of Government Internal Control System does not affect the quality of Central Government Financial Report.

H1 : Implementation of Government Internal Control System affect the quality of Central Government Financial Report. 
4. Organizational commitment has a positive effect on the quality of Central Government Financial Statements, with the hypothesis:

$\mathrm{HO}$ : Organizational commitment has no effect on the quality of Central Government Financial Statements.

H1 : Organizational commitment affect the quality of Central Government Financial Report.

\section{RESEARCH METHODS}

\subsection{Research Design}

The type of research used in this research is to use quantitative with causal or causative relationship, which is aimed to analyze the causal relationship between the (two or more) independent and dependent variables, which influenced and influenced, as stated by Sugiyono (2007). Selection of research methods is based on the collection of data in the form of questions in the form of questionnaires. The questionnaire is a list of written questions previously formulated that will be answered by respondents, usually in clearly defined alternatives. Choice of answers in questionnaires using Likert-scale forms with variables, including implementation of Accrual Based Government Accounting Standards, utilization of information technology, Government Internal Control System, Organizational Commitment, and quality of Central Government Financial Statements. Instrument in question form with five point likert scale with range "Strongly Agree" to 5, that is "Strongly Disagree. The samples in this study are officials / officials at 11 echelon I Ministry of Finance environment responsible for the preparation of financial statements.

\subsection{Data Analysis Method}

Data quality test performed include reliability test and validity test by using correlation technique and chronbach alpha. Reliability test is a tool to measure a questionnaire that is an indicator of a variable or construct. A questionnaire is said to be reliable or reliable if one's answer to the question is consistent or stable over time (Ghozali, 2011). A construct is said to be reliable if it gives a Cronbach Alpha value> 0.60 (Nunally, 1967 in Ghozali, 2005). While the validity test used to measure valid or not valid a questionnaire. A questionnaire is said to be valid if the question on the questionnaire is able to reveal something to be measured by thequestionnaire. 


\section{RESULTS AND DISCUSSION}

\subsection{Description of Data / Research Objects}

The object of the research is in the form of primary data in the form of questionnaires as much as 132 given to the respondents responsible in the preparation of Central Government Financial Statements on 11 units of Echelon I in the Ministry of Finance. Questionaire given to officials / officers responsible for the preparation of Central Government Financial Statements in the Ministry of Finance at the level of echelon I, level of the Ministry of Finance as Chief Operating Officer or Minister of Finance as minister / head of institution and at the level of the Ministry as Chief Financial Offier or Minister of Finance as the Minister of Finance as an assistant to the President in the field of finance. From 132 questionnaires submitted to the respondents, the number of questionnaires returned as many as 100 questionnaires.

\subsection{Analysis of Research Results}

\subsubsection{Validity Test}

Validity test results are parameters in measuring the valid or invalid question in the questionnaire. The questionnaire is valid or valid if the questionnaire is able to reveal something that the questionnaire will measure. The significance test is done by comparing $r$ count with $r$ table for degree of freedom $(\mathrm{df})=n-2$. In this case $n$ is meant the number of samples is $=100-2=98$, with df 98 and alpha $=0.05$ obtained from $\mathrm{r}$ table $=0.165$. The results of validity testing on variables $\mathrm{X} 1$ (Accounting Standards of Government-Based Accrual), X2 (Utilization of Information Technology), X3 (Government Internal Control System), X4 (Organizational Commitment) and and Y (Quality of Central Government Financial Statements) value is above 0.165. Based on the test results it is concluded that there are no Corrected Item-Total Correlation questions that are less than 0.165. Thus it shows 15 questions for the accrual Government Accounting Standards variables, 9 questions on the use of information technology, 22 questions of the Government Internal Control System, 7 items of organizational commitment questions and 15 questions of quality of the Central Government Financial Report are valid questionnaires.

\subsubsection{Reliability Test}

The results of reliability testing show calculation of Cronbachs Alpha Based on Standardized Items of each variable look no one less than 0.6 which means that the construct is reliable.

\subsubsection{Hypothesis Testing Research}

In the table below shows that the sig value of 0.000 less than 0.05 , it shows that all independent variables significantly influence the dependent variable is the quality of the Central Government Financial Statements. 


\begin{tabular}{|l|r|r|r|r|r|}
\hline Model & Sum of Squares & df & Mean Square & F & \multicolumn{1}{c|}{ Sig. } \\
\hline 1 Regression & 481,321 & 4 & 120,330 & 41,771 &, $000^{\mathbf{a}}$ \\
Residual & 273,669 & 95 & 2,881 & & \\
Total & 754,990 & 99 & & & \\
\hline
\end{tabular}

a. Predictors: (Constant), Organizational Commitment, Government Accounting Standards, Information Technology, Government Internal Control System

b. Dependent Variable: Quality of Central Government Financial Statements

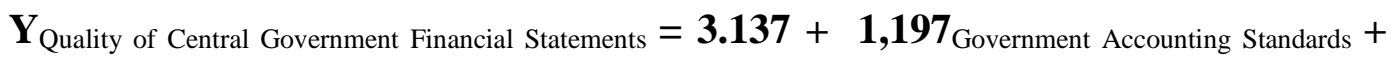
$\mathbf{0 . 0 4 1}$ Information Technology $+\mathbf{0 . 1 5 7} 7_{\text {Government Internal Control System }}+\mathbf{0 . 1 5 1} 1_{\text {Organizational Commitment }}$ $+\mathbf{e}$

Interpretation of the above equation, as follows:

1) Constant of 3.137 means that if the effect of Accounting Standards Based Government Accrual, utilization of Information Technology, Government Internal Control System and organizational commitment Perceptions and Interests, it can be said there is an increase in Decision Selected an increase of 3.137. The regression coefficient of Accounting Standards Based on Accrual Based Accounting of 1,197 means that if the influence of Accounting Standards Based on Accrual Government increases 1 unit, it will affect the Quality of Central Government Financial Statement of 1,197 units.

2) Regression coefficient of information technology

3) utilization of 0.041 means that if the utilization of information technology increased 1 unit, it will affect the increase of the Quality of Central Government Financial Statements 0.041 units.

4) Regression coefficient of Government Internal Control System of 0.157 means that if the Government Internal Control System increases 1 unit, it will affect the increase of the Quality of Central Government Financial Statements 0.041 units.

4.2.4 Regression Coefficient Organizational Commitment of 0.151 means that if the commitment of the organization increased 1 unit, it will affect the increase of the Centra Government Financial Statements 0.041 units

\subsubsection{Partial Hypothesis Test (t test)}

Accounting-Based Government Accounting Standards Variables have t arithmetic $11.37>\mathrm{t}$ table 0.165 with a significance value of 0.000 or less than 0.05 (alpha $\alpha=$ $5 \%$ ), so the hypothesis one (H1) accepted means that the Accounting Standards of Government-Based Accruals significant quality of Central Government Financial Report.

1. Utilization of Information Technolgy Variables have $t$ count $1.201>t$ table 0.165 with significance value of 0.233 or more than 0.05 (alpha $\alpha=5 \%$ ), so the hypothesis one $(\mathrm{H} 2)$ is acceptable means that the utilization of information technology has a positive effect, Central Government Financial Report.

2. Internal Control System Variables The government has $t$ arithmetic 1,170> $t$ tables of 0.165 with a significance value of 0.245 or more than 0.05 (alpha $\alpha=$ $5 \%)$, so the hypothesis one $(\mathrm{H} 3)$ is acceptable means that the Government 
Internal Control System has a positive effect, significant to the quality of Central Government Financial Report.

3. Organizational Commitment variable has $\mathrm{t}$ arithmetic 1,232> t table 0,165 with significance value 0,221 or more than 0,05 (alpha $\alpha=5 \%$ ), so hypothesis one (H4) is acceptable meaning that organizational commitment have positive influence but insignificant to report quality Central Government Finance.

\section{CONCLUSIONS}

\subsection{The Effect of Accrual Based Government Accounting Standards on Quality of Central Government Financial Statements}

The result of data processing in this research shows that there is a positive and significant influence between the implementation of Accrual Based Government Accounting Standards to the quality of Central Government Financial Report. This is in line with the results of research conducted by Dr. Akbar Amini Mehr, Singaporean Journal of Businness Economic \& Management Studies (2015) and discussed the Assessment The Acceptual Acceptance Of Accrual Accounting and Accountability Of The Ministry Of Science Universities that the public sector accrual accounting standards have a significant influence on the validity of the presentation of public sector financial reporting.

\subsection{Effect of Information Technology Utilization on Quality of Central Government Financial Statement}

The results of data processing in this study indicate that there is a positive but not significant influence between the utilization of information technology on the quality of the Central Government Financial Report. This is in line with the results of research conducted by Imraah Maulidia, Rizal Effendi, Cherrya Dhia and discusses the Use of Information Technology on the quality of information on local government financial reports on the dispenda Palembang, which concluded the utilization of information technology has a positive influence on the quality of financial statements.

\subsection{Influence of Government Internal Control System on Quality of Central Government Financial Statement}

The results of data processing in this study indicate that there is a positive but not significant influence between the Government Internal Control System on the quality of the Central Government Financial Report. This is in line with the results of research conducted by Akhmad Syarifudin (2014) and discusses the Government Internal Control System on the quality of information on Local Government Financial Reports in the dispenda of Palembang City, which concludes that the utilization of information technology has a positive influence on the quality of financial statements.

\subsection{The Effect of Organizational Commitment on Quality of Central Government Financial Statements}

The results of data processing of this study indicate there is a positive influence although not significant between organizational commitment to the 
quality of Central Government Financial Statements. This is in line with the results of research conducted by Akhmad Syarifudin and discuss the Effect of Head of Regional Commitment on the Quality of Government Financial Statements in West Java Province on the quality of information, which concludes the commitment of regional heads have a positive influence on the quality of financial statements.

\subsection{Limitations and Research Implications}

1. In this study only uses a limited sample of 11 units of echelon 1 within the Ministry of Finance with the consideration that it is the largest number of financial statement presentation, so that the model obtained tend to be homogeneous. For the next researcher it is suggested to use the sample spread in the heterogeneous area so that the result obtained is varied and complex.

2. This research is conducted on a limited period of time so it is not known exactly what is the main problem in the preparation of Central Government Financial Statements. So for the next researcher, it is advisable to understand more deeply the problems faced by the compilers of financial statements then provide practical solution problems.

\section{REFERENCES}

Cooper \& Schindler (2017). Business Research Methods. Salemba Empat ,Jakarta. Ghozali (2013). Multivariate Analysis. Universitas Diponegoro, Semarang Gujurati, Porter (2010). Fundamentals of Econometrics. Salemba Empat, Jakarta. Jogiyanto. (2008). Information System Research Methodology. Penerbit Andi, Jakarta.

Sekaran, Roger Bougie (2017). Research Methods For Business. Salemba Empat Jakarta.

Akbar Amini Mehr. (2015). Singaporean Journal of Businness Economic \& Management Studies.

Silviana (2012). The Effect of Regional Head Commitment on Quality of Local Government Financial Statement in West Java Province.

Richard M. Steers (Sri Kuntjoro, 2002). Commitmentof Organizational.

Sugiyono (2014). Quantitative Research Methods, Qualitative. Bandung: Alfabeta.

Government Regulation 17 of 2003 onGovernment Finances.

Government Regulation 60 of 2008 onGovernment Internal Control System.

Government Regulation 71 of 2010 on Government Accounting Standards. 